\title{
Income Tax Issues on The Omnibus Law and Its Implications in Indonesia
}

\author{
Prianto Budi Saptono ${ }^{1, a, *}$, Cyntia Ayudia ${ }^{2, b}$ \\ ${ }^{1}$ Faculty of Administrative Science, Universitas Indonesia \\ Jalan Prof. DR. Selo Soemardjan, Depok, Jawa Barat 16424, Indonesia \\ ${ }^{2}$ Pratama-Kreston Tax Research Institute \\ Jalan TB Simatupang, Jakarta Selatan, DKI Jakarta 12530, Indonesia

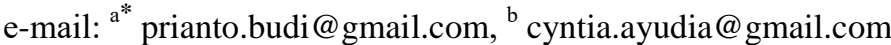 \\ * Corresponding Author
}

\begin{abstract}
This research has two objectives. The first objective is to analyze the issue of income tax policy based on the idea of taxation omnibus law. In 2020, Law No. 36 of 2008 concerning Income Tax was amended twice as stipulated in Law No. 2 of 2020 and Law No. 11 of 2020 (Job Creation Law). The second objective is to analyze the implications of income tax policy changes on taxation practices in Indonesia. This research is a descriptive qualitative study using data collection techniques in documentation and literature studies. The research concludes that the omnibus law policy aims to encourage domestic investment funding. Income tax issues in Law No. 2 of 2020 include lowering the corporate income tax rate and imposing taxes on trade through an electronic system. Besides, the issue of income tax in Law No. 11 of 2020 includes tax subjects' determination, the territorial system's adoption, tax objects' exclusion, and changes to the provisions on dividends. The implication of the change in income tax policy on taxation practices is that taxes distort the economy. The delegation of regulations for reducing income tax rates to the government through government regulations creates legal uncertainty. Thus, it is necessary to have tax regulations with minimal complexity, not overlap, provide legal certainty, and further encourage voluntary tax compliance.
\end{abstract}

Keywords: income tax, omnibus law, job creation

Article History: Received: February 32021 Accepted: March 22021 Published: April 52021

How to cite: Saptono, P.B. \& Ayudia, C.(2021) Income Tax Issues on The Omnibus Law and Its Implications in Indonesia . Akrual: Jurnal Akuntansi (JA)12(2): 164-178. DOI: https://doi.org/10.26740/jaj.v12n2.p164178

\section{INTRODUCTION}

In the past five years, global conditions have been in the shadow of economic slowdown and uncertainty. However, according to data from the Central Bureau of Statistics (2020), amid dynamic change and global economic uncertainty, Indonesia's financial performance in Q3 2019 quite well with a growth of 5.02\%. However, Indonesia still has vulnerabilities due to some factors, including several domestic investment regulations that do not support and hinder investment, such as the Corporate Income Tax rate, which is considered less competitive than ASEAN countries. This factor has also led to tax avoidance practices through profit shifting and giving rise to businesses' tendency to invest abroad. 
Various government efforts to improve the investment climate still do not attract investors to invest in Indonesia. The government has issued Government Regulation No. 24 of 2018 concerning Integrated Electronic Business Licensing Services. The facts show that the Online Single Submission (OSS) business process simplification still raises obstacles and has not yet produced significant outcomes. Based on a report entitled "Doing Business 2020", the World Bank (2020) noted that Indonesia had made improvements in several aspects so that the business ease score increased by 1.64 points to 69.6. However, Indonesia's ranking in the Ease of Doing Business (EoDB) index remains stagnant at 73 despite efforts to attract investment by removing hostile regulations.

Directorate General of Taxation explained that one of the tax revenue optimization efforts is implementing the omnibus law. Tax optimization is obtained not only from broadening the tax base but also through improving policy and administration. One is to minimize tax uncertainty, which is the basis for achieving a suitable taxation model for businesses (Owens, 2019). The leading causes of tax uncertainty are tax laws' complexity, including documentation requirements, inconsistent tax authorities' decisions, and the inability to achieve tax certainty through the ruling mechanism (OECD, 2017).

Based on the 2020 National Legislation Program, the government proposed two bills. It used the omnibus law method, namely the Bill on "Tax Provisions and Facilities for Strengthening the Economic" and the Bill on "Job Creation." The omnibus law idea is a legal breakthrough considering the need to solve various overlapping regulations through synchronization into one comprehensive law. The omnibus law on the taxation field simultaneously changes several areas as an efficient measure compared to waiting to discuss each taxation law. Various factors underlie this condition include volatility in commodity prices, disruption of the global supply chain due to trade wars, uncertain financial markets, and the coronavirus disease's impact (Covid-19).

On March 11, 2020, the World Health Organization declared Covid-19 as a global pandemic. The spread of this virus has caused a health crisis in various parts of the world and a recession, specifically a slowdown in national economic growth. Pandemic conditions are one of the government's driving factors to establish policies regarding financial system stability through the ratification of Law No. 2 of 2020 (from now on, "Law 2/2020"). Furthermore, the government officially enacted Law No. 11 of 2020 (from now on, "Law 11/2020") concerning Job Creation on November 2, which led to various community reactions. This study will analyze the income tax policy issues in both regulations and its implications for taxation practices.

\section{RESEARCH METHOD}

This study is a descriptive qualitative research that focuses on income tax policy issues in the omnibus law and its implications. The study describes social phenomena and their characteristics, emphasizing the research's social realities (Nassaji, 2015; Wagner et al., 2012). The aspects described in detail in this study are issues or problems in implementing income tax based on applicable regulations. This research uses a systematic review approach to analyze the problems. A systematic review strives comprehensively identify, evaluate, and synthesize all available research evidence concerning a specific subject or relevant to a particular research question, topic area, or phenomenon of interest (Kitchenham \& Charters, 2007; Petticrew \& Roberts, 2006; Victor, 2008). Systematic reviews aim to present a fair evaluation of a research topic using a transparent and rigorous 
way to enhance the findings' validity and reliability (Victor, 2008). The data collection technique used documentation study through literature with qualitative data analysis.

\section{RESULTS AND DISCUSSION}

In 2020, Law No. 36 of 2008 concerning Income Tax was amended twice as stipulated in Law 2/2020 and Law 11/2020 (Job Creation Law). The establishment of Law 2/2020 is an extraordinary measure and a quick response from the government to an uncertain economic situation related to handling the Covid-19 pandemic. It aims to restore and strengthen the economy, including the affected business sector and society. Through this regulation, the government establishes a financial state policy and a financial system stability policy.

Taxation policies are within the scope of financial state policies. In general, this provision regulates, among others, 4 (four) tax policies. First, a reduction in the Corporate Income Tax (CIT) rate and Permanent Establishments (PE), namely 22\% for the 20202021 tax year and 20\% starting from the 2022 tax year. Second, trade tax treatment through Electronic Systems (Perdagangan Melalui Sistem Elektronik; PMSE). Third, an extension of the time to exercise rights and fulfillment of tax obligations. Fourth, granting authority to the Minister of Finance to provide customs facilities in the form of exemption or relief from import duties.

Furthermore, Article 1 point 1 of Law 11/2020 defines Job Creation as an effort to create work through efforts to facilitate, protect and empower small enterprises, increase the investment ecosystem, and EoDB index acceleration of national strategic projects. Law $11 / 2020$ pays attention to areas that facilitate a simple, easy, and fast business process. This policy is also one of the measures to strengthen the Indonesian economy, specifically in encouraging investment amid a global economic slowdown and absorbing the broadest possible workforce opportunity. However, according to Riyanto et al. (2020), the Job Creation Law cannot quickly resolve excessive and overlapping regulations problems in the Indonesian legal system. It requires the existence of around 500 derivative rules and potentially creates complex hyper-regulated ones.

The Job Creation Law consists of 15 Chapters and 186 Articles by amending 78 Laws. Part Seven of Chapter VI, Ease of Doing Business, covers the taxation cluster. The tax cluster in Law 11/2020 includes 4 (four) laws divided into Articles 111 to 114. Article 111 contains the Income Tax Law amendments. Table 1 summarizes the scope comparison of the Income Tax sector in Law 2/2020 and Law 11/2020 as follows:

Table 1. Comparison of the Income Tax Amendments in Law 2/2020 and Law 11/2020

\begin{tabular}{clll}
\hline \multicolumn{1}{c}{ No. Purpose } & \multicolumn{1}{c}{ Law No. 2 of 2020 } & \multicolumn{1}{c}{ Law No. 11 of 2020 } \\
\hline 1 & Increase & [1] Gradual reduction of corporate & [1] Elimination of domestic \\
Investment & income tax rates by 22\% (in 2020 & income tax on dividends \\
& Funding & \& 2021) and 20\% (2022 onwards) & [2] Dividends and profit after tax \\
& [2] A decrease in corporate & from abroad are not subject to \\
& income tax rates for go-public & income tax as long as they are \\
& taxpayers (3\% reduction from & invested in Indonesia \\
& general rate) & [3] Non-object of income tax on \\
& & (a) the profit share of the \\
& & cooperative's operating income, \\
& & and (b) the hajj funds managed by \\
& & the Hajj Financial Management
\end{tabular}




\begin{tabular}{ll}
\hline & Agency \\
& [4] Space for interest tax rate \\
Increase & adjustment of Article 26 \\
Legal & [1] Determination of individual \\
Certainty & tax subjects: \\
& a. Indonesian citizens and \\
& foreigners living $>183$ days in \\
& Indonesia become Domestic Tax \\
& Subjects \\
& b. Citizens residing in Indonesia \\
& 183 days can become Foreign Tax \\
& Subjects with certain conditions \\
& [2] The imposition of income tax \\
& for foreign citizens who are \\
domestic tax subjects with & specific expertise only on income \\
from Indonesia (source principle) & [3] Non-object of income tax on \\
the remaining funds from Social \\
Agencies, Religious Bodies, and \\
Educational Institutions
\end{tabular}

Source: Directorate General of Tax (2020), "Undang-Undang Nomor 11 Tahun 2020, Klaster Kemudahan Berusaha: Bidang Perpajakan"

Income Tax Policy Issues According to Law No. 2 of 2020

In connection with the income tax issue, Article 17 paragraph (2a) of the Income Tax Law No. 36 of 2008 regulates the corporate taxpayer income tax rate of $25 \%$, which can be reduced by $5 \%$ by meeting specific requirements based on Article 17 paragraph (2b). Through Law 2/2020, the CIT rate will be gradually reduced by 22\% in 2020-2021 and $20 \%$ starting from 2022. It is also reducing the go-public company's (the total number of paid-up shares traded on the stock exchange in Indonesia is at least $40 \%$ and meets several requirements) CIT rate by $3 \%$ from the general rate.

The policy background for reducing CIT rates is national economic growth, which requires private sector investment funding, so it is necessary to increase its contribution. Other countries have also undertaken a similar response aimed at stimulating the economy. In line with global trends, efforts to promote competitiveness through tax instruments have become the tax reform agenda in various countries (OECD, 2018), reducing the tax rate and expanding the tax base. This trend indicates that various countries use tax instruments to compete for capital and investment (Abbas et al., 2012, p. 1). Primarily due to the Covid-19 pandemic, every country needs to stimulate the domestic economy.

For example, the United States implemented a tax reform known as the Tax Cut and Jobs Act (TCJA) in 2017, which is proven to help economic growth and job creation (Kumar, 2020). Some of the tax reform features include reducing the CIT rate, various tax breaks for individuals, and a territorial tax regime on certain income of companies from abroad (Tax Policy Center, 2017). Furthermore, several countries, such as Denmark, Ireland, Canada, and other Organization for Economic Co-Operation and Development 
(OECD) countries, also took part in tax relaxation. For example, the reduction of CIT rates by France, Luxembourg, and Norway between 2019 and 2021 (OECD, 2019).

The intensity of the tariff reduction competition has put pressure on every country to lower its rate. Over the last two decades, there has been a competitive trend of decreasing CIT rates (race to the bottom), which has decreased by $7.4 \%$ on a global average (OECD, 2020). Its main target is to attract investment and promote economic growth, not in the context of international war tax rates. Table 2 summarizes the comparison of CIT rates globally in 2010-2020 as follows:

Table 2. Comparison of 2010-2020 Corporate Income Tax Rates (\%)

\begin{tabular}{llllllllllll}
\hline $\begin{array}{l}\text { Average } \\
\text { Corporate } \\
\text { Income Tax }\end{array}$ & 2010 & 2011 & 2012 & 2013 & 2014 & 2015 & 2016 & 2017 & 2018 & 2019 & 2020 \\
Rates (\%) & & & & & & & & & & & \\
\hline Global & 24,65 & 24,52 & 24,38 & 24,17 & 23,88 & 23,77 & 23,62 & 24,06 & 24,05 & 23,81 & 23,79 \\
OECD & 25,70 & 25,42 & 25,18 & 25,32 & 24,98 & 24,77 & 24,69 & 23,95 & 23,53 & 23,23 & 23,05 \\
Europe & 21,46 & 20,83 & 20,44 & 20,60 & 20,42 & 20,05 & 19,97 & 19,53 & 19,48 & 19,26 & 19,12 \\
Asia & 23,72 & 22,91 & 22,72 & 22,13 & 22,00 & 21,98 & 21,41 & 21,08 & 21,21 & 21,18 & 21,13 \\
Africa & 28,49 & 28,64 & 29,07 & 28,33 & 27,83 & 28,14 & 28,03 & 28,21 & 28,26 & 28,23 & 28,25 \\
\hline
\end{tabular}

Source: KPMG (2020), "Corporate Tax Rates Table for 2010-2020"

The high corporate income tax rate is considered less supportive of the domestic business sector and reduces Indonesia's competitiveness in attracting investment compared to ASEAN countries. The pressure from the downward trend in corporate income tax rates has encouraged Indonesia to gradually and measurably follow these steps as a signaling way that Indonesia has the intention to be competitive at the global level. Based on this background, the Indonesian government (2019) stated that tax rate reduction is necessary to make Indonesia's CIT rate more competitive to attract investment from abroad. The rate reduction is also relatively fairer because it applies to all corporate, not only giving tax incentives to specific taxpayers. The government projects this policy can ensure domestic capital maintenance and encourage foreign capital inflow to drive the country's real sector.

Therefore, the reduction CIT rate for companies at least $40 \%$ owned by the public show that the government aims to encourage corporate taxpayers' behavior to sell their shares publicly. As is known, with the increase in the number of companies listed on the Indonesia Stock Exchange, the efficiency of corporate activity funding can increase, one of which is through public involvement so that the stock market can allocate sufficient funds to developing companies (Kee-hong \& Jisok, 2017). This step also triggers transparent corporate governance due to the obligation to submit financial reports that a public accountant has audited. In the end, economic productivity growth will remain stable.

The next issue is the imposition of income tax on trade through an electronic system with a withholding tax system and must comply with the source principle's nexus rules. The current regulations on the income obtained from PMSE activities by domestic tax subjects (Subjek Pajak Dalam Negeri; SPDN) are subject to tax following the Income Tax Law provisions. The fundamental issue in PMSE activity taxation carried out by foreign tax subjects (Subjek Pajak Luar Negeri; SPLN) is that conceptually determining the distribution of taxation rights still depends on a permanent establishment with physical 
presence criteria. OECD (2015) states that the concept of determining physical presence as a profit generator should have a broader meaning by considering the conditions and location of economic activities that generate profits.

The concept of determining the existence of a business form related to the actual activities of an entity to create profit within a jurisdiction is important considering current technological advances. One of the characteristics of the digital economy is the mobility of business functions. The current development of information and communication technology increases companies' flexibility in placing their business functions in various jurisdictions (Darussalam et al., 2020). Technological developments allow an entity to significantly influence a business without having a fixed place or dependent agent.

The currently developing digital economy pattern raises taxation on digital transactions, including the issue of inequality of treatment due to the development of the digital economy for the people of jurisdiction and the risk of tax avoidance in the PMSE scheme in the form of eroding the basis of taxation. This condition is a consequence of shifting transactions from conventional to electronic. The digital economy condition presents various new businesses that opening up opportunities for new legal tax avoidance schemes (Firmansah \& Rahayu, 2020, p. 1). For example, they operate a business without a physical presence and are not taxable in that country. Digital business actors widely use the loophole in practicing tax avoidance by deliberately designing their business models in such a way as to utilize information and communication technology. This practice resulted in a loss of tax revenue globally by reducing the tax base.

More specifically, the OECD (2015) identifies several profit shift issues in the PMSE scheme to avoid taxation in jurisdictions where economic transactions or activities occur, including: (i) avoiding being a tax object; (ii) minimizing income in market jurisdictions by allocating income to functions, assets or risks; and (iii) maximizing costs or reducing income in market jurisdictions. In the end, the international consensus application that requires a company's physical existence in a country to become a $\mathrm{PE}$ is finally considered obsolete in the era of the digital economy. Digital companies can make substantial profits in a country via the internet without performing a business function or creating any physical presence (Huibregtse \& Sood, 2016, p. 101). Therefore, a country must have special arrangements to protect the tax base from changing its digitalized business model.

According to Law 2/2020, Indonesia regulates the imposition of income tax on foreign traders, foreign service providers, or foreign PMSE providers who meet specific criteria in the form of significant economic presence, including (i) gross revenue from business group consolidation up to a certain amount; (ii) sales in Indonesia up to a certain amount; and (iii) up to a certain number of active digital media users in Indonesia. The government projects this policy to mitigate tax avoidance risk and provide equal treatment for business actors between conventional and electronic commerce. Furthermore, so that Indonesia is not only a market but also involved as an actor in economic interaction.

However, the nexus rules in the form of a significant economic presence may collide with the existence of a Double Taxation Agreement, which still uses the physical presence requirement not to be subject to income tax. In that case, foreign service providers or PMSE operators abroad who meet the provisions of this significant economic existence are subject to electronic transaction tax (Pajak Transaksi Elektronik; PTE). Article 32A of Law No. 36 of 2008 authorizes the government to sign a tax treaty so that the legal rule 
"lex specialis derogat legi generali" applies. The basis for imposition, rates, and procedure for calculating income tax and PTE are regulated by or based on a Government Regulation.

According to Darussalam, Septriadi, and Kristiaji (2020), essential things need attention to ensure harmony with global consensus, especially the Anti-BEPS Project. The challenge in taxing the digital economy-related to BEPS lies in technical difficulties in designing policies that can provide a fair allocation of rights and do not erode the tax base due to tax avoidance and evasion. The income tax regulation on foreign PMSEs only guarantees Indonesia's taxation rights through a significant economic presence but does not yet regulate Indonesia's taxable profit base. Taxation of income through PE based on the manifestation of a significant economic presence and electronic transactions can be an appropriate step to ensure the level playing field of taxation between foreign and domestic digital players in Indonesia without disrupting terms of legality.

\section{Income Tax Policy According to Law No. 11 of 2020}

Concerning the scope of income tax in the Job Creation Law, there are changes to 3 (three) articles of Law 36/2008, namely Article 2, Article 4, and Article 26. The characteristic of income tax as a direct tax implies that the provisions regarding objects, rates, and calculating the income tax debt will directly impact the business's economic value in a jurisdiction. Researchers highlight that there are at least 5 (five) tax issues in this study. First, to increase taxpayers' legal certainty, Law 11/2020 accommodates changes in regulations regarding individual tax subjects' determination. The previous rule only mentioned the criteria for a person without mentioning citizenship status.

Based on Article 2 paragraph (3) of Law 36/2008, Indonesia adheres to the principle of domicile, which is to impose a tax on income received or obtained by an individual who resides or has been in Indonesia for more than 183 days in the last 12 months, or an entity that is domiciled. Residing in Indonesia means that the individual is a resident or Indonesian citizen. The jurisdictional uncertainty issue for tax purposes is related to technological progress, increasingly rapid globalization, and increased mobilization between countries. In this case, individuals have a very high cross-border movement intensity and have income sources from abroad.

However, based on Article 2A paragraph (1) of Law 36/2008, it states that "... the obligations of such an individual end when he dies or leaves Indonesia for good." This provision can create uncertainty about whether the treatment of these individuals as domestic taxpayers because many Indonesian citizens live to work or study abroad for a certain period but do not intend to leave Indonesia forever. This category cannot apply the treatment as a foreign tax subject. Thus, the basic concept underlies the main determinants of tax subject in a country requires legal certainty. Whether permanent residence, family connection, citizenship status, physical presence, habitual abode, or a place to carry out economic and social activities (center of vital interests).

Through Law 11/2020, Indonesian citizens and foreigners in Indonesia or have been in Indonesia for more than 183 days within 12 months are included in a domestic taxpayer's definition. Furthermore, the Job Creation Law adds to the provisions of Article 2 paragraph (3) and (4) of the Income Tax Law by introducing the principle of nationality in determining tax subjects, particularly foreign tax subjects. In this amendment, foreigners and Indonesian citizens (diaspora) who have lived for less than 183 days in Indonesia or 
more than 183 days abroad who meet specific requirements can become foreign tax subjects. These requirements include (i) residence; (ii) main activity centers; (iii) a place of practice; (iv) tax subject status; or (v) other specified requirements. However, applying the principle of nationality in determining tax subjects has procedural consequences that can cause tax collectors and taxpayers' inefficiency (Riyanto et al., 2020). The application of the principle of nationality in determining the tax subject must be in line with the amendments of general tax provisions law, which regulate the obligation of annual tax returns, tax audits, issuance of tax assessments, and the imposition of sanctions.

Second, the income tax issues that arise in Law 11/2020 are inseparable from the practice of tax reform. Several countries have relaxed various tax policies to create better economic growth. The current trend in OECD countries is the shift of the taxation system worldwide to territorial. However, in practice, the facts show that no single country applies both taxation systems purely, either worldwide or territorial (Fleming et al., 2008).

Based on Article 4 paragraph (1) of Law 36/2008, the income that becomes the object of income tax requires a broad understanding. Currently, Indonesia applies a worldwide income system, both for entities and individuals. Elucidation of Article 2 paragraph (2) of the Income Tax Law clarifies this principle that domestic taxpayers are subject to tax on income received from and outside Indonesia (domestic and foreign). In contrast, foreign taxpayers are taxed only on income originating from Indonesia.

Through Law 11/2020, Indonesia's income tax system now applies a partially territorial system. Contrary to the income tax calculation system based on worldwide income, the income tax calculation based on the territorial system calculates taxable income only from within the country. The tax calculation does not include income originating from abroad. The Job Creation Law stipulates that foreigners who have become domestic taxpayers are subject to tax only on income from Indonesia provided that: (i) have specific expertise, and (ii) are valid for four tax years counting from being subject to domestic tax. This provision covers income connected with work, services, or activities.

Riyanto et al. (2020) criticized several technical matters; for example, using the parameter "certain expertise" has no conceptual basis and tends to be arbitrary. Following the subjective tax concept, the difference in income tax treatment is only under the tax subject's ability to pay for any other reason. Also, the absence of a subject-to-tax clause for foreigners who become domestic taxpayers can result in non-taxation, a condition in which a person is not subject to domestic tax in any country. This situation is undoubtedly contrary to Indonesia's commitment to eradicating tax avoidance and evasion practices.

Third, the issue of eliminating income tax on dividends from within the country. The elimination of domestic and foreign dividends is one instrument to increase Indonesia's attractiveness as an investment destination country. This policy aims to encourage conglomeration practices, mergers, and the establishment of subsidiaries, which leads to the reinvestment of dividend receipts, thereby encouraging the investment climate. Based on Article 4 paragraph (3) of Law 36/2008, the exemption from dividends as an income tax object may apply if it meets the minimum requirements for share ownership and a source of dividends, which comes from retained earnings reserves. Domestic corporate taxpayers' dividends with ownership $\geq 25 \%$ are not subject to income tax, while ownership $<25 \%$ is subject to regular income tax rates. Meanwhile, from a tax perspective on the company concerning individual shareholders, Indonesia adopts a classical system. 
The classical system collects income tax on business profits that imposes corporate income tax at the corporate level and personal or corporate income tax at the shareholder level, resulting in double economic taxation. The classical system views the company as a separate entity from its owners so that the company's income is subject to separate taxation from its shareholders. It means, based on the standpoint of a separate entity system, the same profit or dividend income will be taxed twice, namely at the corporate level and at the level of an individual as a shareholder of a company (shareholder level) (Harris, 2013, p. 251). In domestic dividend distribution, classical system mitigation is through the imposition of a final income tax of $10 \%$ if the shareholder is an individual.

As a consequence, this classical system also encourages the formation of tax avoidance behavior. To avoid taxes on dividends, shareholders tend to withhold profits at the company level deliberately. Companies tend to try to increase retained earnings and reduce the share of dividends. Also, there have been disguised dividends, concealment of beneficial owners, and a re-routing investment scheme as tax planning. Considering the above impacts, it is not surprising that many countries have now adopted both imputation and full integration systems (Cnossen, 2015; Darussalam et al., 2020).

Through Law 11/2020, the regulation changes into dividends originating from within the country received by (i) domestic individual taxpayers, as long as investment in Indonesia is within a certain period, and (ii) domestic corporate taxpayers are not subject to income tax. Thus, this clause's existence will indirectly change income tax treatment on dividends from within the country from a classical system to a one-tier system. It equates to income tax treatment on operating profits or income received by partnerships, limited liability companies, associations, partners, firms, and a collective investment contract. This policy creates a level playing field between various business entities.

Fourth, the issue of the tax treatment of dividends and other income from abroad. Based on Article 4 paragraph (1) of the Income Tax Law, Indonesia adheres to a worldwide income system. Income originating from within and outside the country is subject to income tax in Indonesia, including dividend distribution from overseas business entities. Referring to this regulation, if Indonesian domestic taxpayers have capital participation in companies abroad and receive dividends, then the dividends are the income tax object, and Indonesia is entitled to impose taxes. However, if there is a postponement of dividend distribution, Indonesia does not have the right to tax.

There is a trend of transforming the tax system in OECD countries from worldwide to a territorial system. It aims to address weaknesses in a worldwide system, including the imposition of foreign dividend income tax can trigger company inversion, namely the transfer of parent or holding entities and the transfer of substantial economic activities to countries with a territorial system as the practice of transferring profits. These practices are fundamentally detrimental because funds or capital that should have returned to Indonesia were channeled and left abroad.

Following the OECD Base Erosion and Profit Shifting (BEPS) action, Indonesia has already implemented Control Foreign Company (CFC) rules to prevent tax evasion. Besides, in taxing foreign income, it is inseparable from the Foreign Tax Credit to avoid double taxation. Thus, tax imposition is carried out through a tax calculation or crediting mechanism if the foreign party has withheld tax for income originating from abroad and 
received by domestic taxpayers. However, the government needs to review the provisions regarding Foreign Tax Credit and the provisions of CFCs.

The CFC provisions have been an instrument that aims to uphold Indonesia's worldwide system because of its nature to prevent tax deferral behavior. The change towards foreign dividend exemption can reduce the disincentive to avoid dividend tax. It does not mean that the foreign dividend exemption will automatically push the entire dividend distribution into the country. Therefore, $\mathrm{CFC}$ provisions are still relevant but with a specific design to prevent tax avoidance practices by incorporating the $\mathrm{CFC}$ criteria in a country with an effective tax rate lower than Indonesia (locational test).

Law 11/2020 amends Article 4 paragraph (3) letter $\mathrm{f}$ of the Income Tax Law concerning the exemption of dividends from income tax objects. The exemption from the imposition of income tax on dividends as long as it meets certain conditions requiring reinvestment in the Republic of Indonesia's territory at least 30\% of the dividends received by tax subjects in Indonesia within a certain period. More specifically, this provision contains the main changes regarding dividends and after-tax income from abroad (from gopublic companies or private companies abroad) that are not subject to income tax. Valid for investment to support other business activities in Indonesia for a certain period.

The detailed provisions are as follows: (i) dividend investment in Indonesia is not subject to income tax; (ii) if the amount of dividend investment is $<30 \%$ profit after tax of a foreign business entity, the difference of $30 \%$ minus realized investment in Indonesia is payable with Income Tax; (iii) the remaining profit after tax of the Overseas Business Entity is not subject to income tax. Then, income from abroad not through a PE is not subject to income tax in terms of investment in Indonesia for a certain period and meets the following requirements: (i) income comes from active overseas businesses, and (ii) not income from companies abroad. The purpose of amending the income tax provisions on dividends is to increase domestic investment funding from individual taxpayers or entities that receive dividends and certain income from abroad. The objectives of the exemption of income tax imposition on dividends from abroad as long as investment in Indonesia territory can encourage domestic investment funding to be maintained and provide incentives for dividend diversion in the form of investments that can drive the economy.

However, if Indonesia only modifies its taxation system from a worldwide to a hybrid worldwide or imposes a territorial system only on specific income from abroad, there will be several consequences. In the context of cross-border dividend distribution, the classical system's application will result in juridical double taxation if there is no mitigation by the provisions in a tax treaty. Double taxation arises when the payment of dividends by a corporate taxpayer is payable by income tax in the source state. When an entity distributes dividends to shareholders who have a domicile in the country of residence, it becomes the income tax of individuals or entities in that country.

This provision reduces the income tax base and thus requires anticipation of potential lost revenue. The government predicts that the potential loss of income from dividend income tax write-off will recover in the long term due to the projected increase in investment after the omnibus law bill takes effect. The impact of the loss of income from the exemption from domestic dividend tax must be in balance with the returns on increased domestic investment activity. The government needs to prioritize domestic investment requirements. If not, shareholders' tax savings will increase the wealth of the rich and create further inequality. However, the existence of an amendment will have positive 
implications. It can eliminate double taxation, a relatively better effective tax rate than ASEAN countries, and a healthier change in domestic companies' funding structure.

Fifth, the main point of the last amendment related to Income Tax in the Job Creation Law is that there is space for the tax rate on interest adjustments in Article 26. In the previous regulation, Law 36/2008 stipulates that income tax Article 26 on foreign taxpayers' domestic interest income other than a PE is subject to $20 \%$ or based on the Double Taxation Agreement. Indonesia's 20\% tax rate on interest is among the highest in the ASEAN region. This rate is one of the barriers to the entry of domestic investment because it affects investors' interest to finance their investment domestically in the form of loans due to the high cost of capital in Indonesia, which will affect investors' returns.

Law 11/2020 adds to Article 26 paragraph (1b) of the Income Tax Law, which stipulates that the income tax Article 26 rate is $20 \%$ of the gross amount by parties obliged to pay interest can lower with a Government Regulation. The interest, including premiums, discounts, and rewards in connection with debt repayment guarantees. The objectives of reducing income tax rates include creating level playing fields for investors and increasing foreign or domestic investors' interest to participate in the development. The government projects that the tariff adjustment policy can increase company financing, which will increase the company's production capacity and improve Indonesia's competitiveness.

\section{Implications for Tax Practice}

In general, taxes have a distortionary effect on the economy (Suratman, 2009, p. 125). All taxes affect behavior and cause distortions related to individual actions to avoid taxes (Stiglitz, 2000, p. 463). Introducing special tax provisions for these conditions (for example, the difference in rates) will create discrimination between business models. This discrimination will reduce neutrality, which will distort economic decisions (Stewart, 2015). Taxes encourage buyers and sellers in an economy to change their behavior (Mankiw, 2018, pp. 159-160). Simultaneously, a person's behavior will adjust to tax regulations, and compliance behavior will be affected.

Several income tax policy improvements in the omnibus law aim to provide incentives or tax reductions to reduce distortions. Logically, when tax regulations are more "friendly" to the investment, the business sector can develop its business so that it is in line with the increasing number of taxpayers and leads to voluntary compliance. Taxpayer compliance is a very complex behavioral issue and an essential role in determining the tax revenue amount (Diamastuti \& Hardanti, 2019). From the entrepreneur's side, the income tax regime that applies in a country is one factor in determining investment location (apart from geographical location, infrastructure, and employment).

According to Law 2/2020, the CIT rate reduction has reduced the "distance" of Indonesia's CIT rate from other countries. This policy can positively reduce the risk of profit-shifting practices through various schemes such as transfer pricing manipulation and thin capitalization (Devereux \& Maffini, 2006). Profit shifting arises from the opportunity of an international tax system that provides flexible taxation right over each jurisdiction. However, on the other hand, the reduction in CIT rates reaps the pros and cons. It also has to note that the larger country's economy, the greater loss of state revenue due to reduced tariffs because each country has different capabilities and sacrifices. As a result, developing countries with large economies, such as Indonesia, will be more challenging to 
reduce CIT rates than other countries. For countries with a lower economic base, small populations, and less dependent on tax revenues, the reduction in corporate income tax rates has no significant impact (lower worse-off) (Keen \& Simone, 2004).

Furthermore, the effect of low corporate income tax rates on investment is debatable (Mooij \& Saito, 2014). According to Peter Diestch (2015), tariff competition is relatively more favorable to those who cut their taxes from the start (first-mover advantage), such as Singapore and Ireland. Furthermore, the relationship between tariff reduction and compliance is unclear (Darussalam, 2020). Although the classical theory of taxpayer behavior shows that a higher tax rate encourages the desire to disobey (Allingham \& Sandmo, 1972), empirically, the results still show ambiguity. Compared to the rate reduction, the existence of an anti-tax avoidance provision instrument is considered more effective in preventing the practice of profit shifting.

Besides, lowering the CIT rate can impact tax revenue in the short term. The government has estimated that there will be a revenue forgone of up to IDR 87 trillion (Tempo, 2019). Therefore, to anticipate revenue forgone, it is necessary to make various breakthroughs in expanding the tax base. This strategy is in line with the term broad base low rate developing in the trend of tax reform (OECD, 2010). Expand the tax base through adding taxpayers, preventing the tax base from scouring through strong anti-tax avoidance provisions (OECD, 2019), and adding new tax objects, including consumption-based taxes and personal income. Thus, the effort to attract investment reduces the CIT rate simultaneously with tax-based protection measures (Darussalam, 2020) to offset tax relaxation. Therefore, the reduction in CIT rates needs to be accompanied by considerations to the effective tax burden comprehensively and improve other factors that support the investment climate.

Furthermore, based on Law 11/2020, the rules regarding the determination of Individual Tax Subjects and the worldwide system change to territoriality can have implications for increasing legal certainty and voluntary taxpayer compliance. In general, implementing a territorial taxation system can encourage repatriation because income from abroad to Indonesia is not taxable. Besides, this policy aims to increase competitiveness in attracting international business actors to place their headquarters in countries with territorial systems. Tax facilities for foreigners subject to domestic taxes can attract the diaspora to return to Indonesia and anticipate a brain drain. However, on the other hand, these facilities can provide incentives for foreign workers' entry into Indonesia (labor influx). Local workers' access to the labor market will be increasingly difficult.

The implementation of the territorial taxation system will reduce the tax base, resulting in state revenue decrease. Also, there is a risk of harmful tax preferential regimes by individual tax subjects if the expatriate regime is not well designed. The system's application has triggered unfair competition between countries in attracting international business actors due to tax exemptions and facilities. The regulation of tax facilities for foreigners who are domestic tax subjects can lead to reverse discrimination, which is when foreign citizens' tax treatment is better than those of Indonesian citizens. Meanwhile, both are domiciled in Indonesia and have the same economic conditions or carry out identical transactions. In international tax law, the prohibition against such discrimination is in Article 24 of the Double Taxation Avoidance Agreement, especially those which adopt the OECD Model Tax Convention. 
Besides, it should be taken into consideration that the Income Tax Law amendments in the Job Creation Law do not have transitional provisions regarding when these changes take effect. The void of transitional provisions is inconsistent with the non-retroactive tax collection principle, requiring that tax laws and regulations cannot be retroactive. At the same time, income tax is imposed on the tax subject on the income received or earned in the tax year, unless the taxpayer uses a different accounting year. Furthermore, the delegation of income tax rate arrangements to the Government Regulation is certainly creating legal uncertainty. The principle of legal certainty requires that the law regulates the subject, object, rate, and method of paying taxes.

However, various changes or adjustments to the provisions in a single taxation omnibus law can minimize the cost of collecting and fulfilling tax obligations. Economically, tax authorities expect administrative costs to be minimal. From the taxpayer's point of view, he expects that complying with tax obligations (compliance cost) is minimal. According to Stiglitz (2000, pp. 458-461), the "economic efficiency" principle emphasizes that the tax system should not cause economic distortions.

\section{CONCLUSION}

The Amendment to the Income Tax Law originated from an omnibus law aiming to solve various overlapping regulatory problems and encourage domestic investment funding. The issue of income tax in Law 2/2020 includes a gradual reduction in the corporate income tax rate to increase investment competitiveness and a policy to impose taxes on trade through an electronic system to create a level playing field. However, Indonesia is in a more difficult position to lower the corporate income tax rate because it has a large economy and impacts tax revenue loss in the short term. The relationship between tariff reduction and the level of taxpayer compliance is still a debate. Furthermore, the five income tax issues in Law $11 / 2020$ as a "one-size-fits-all" rule, including (i) determining individual tax subjects; (ii) transfer of the taxation system from worldwide to hybrid worldwide or territorial for specific income; (iii) write off domestic income tax on dividends; (iv) tax treatment of dividends and other income from abroad; and (v) the availability of space for the adjustment of interest rate on Income Tax Article 26.

The implication of the change in income tax policy on taxation practices is that taxes distort the economy. The delegation of regulations for reducing income tax rates under government regulations can create legal uncertainty, as the government can change at any time without parliamentary approval. A person's behavior will adjust to tax regulations, as well as tax compliance behavior. Thus, it is necessary to have tax regulations with minimal complexity, not overlap, provide legal certainty, and further encourage voluntary tax compliance. Voluntary compliance can have implications for lower collection fees or costs.

\section{REFERENCES}

Abbas, S. ., Klemm, A., Bedi, S., \& Park, J. (2012). A Partial Race to the Bottom: Corporate Tax Developments in Emerging Markets. In IMF Working Paper (Vol. 12, Issue 28).

Allingham, M. G., \& Sandmo, A. (1972). Income Tax Evasion: A Theoretical Analysis. Journal of Public Economies, 323-338. 
Saptono\&Ayudia. Income Tax Issues on The Omnibus....

Badan Pusat Statistik. (2020). Berita Resmi Statistik: Pertumbuhan Ekonomi Indonesia Triwulan IV-2019. In Badan Pusat Statistik (Issue 17/02/Th. XXIV). https://www.bps.go.id/pressrelease/2020/02/05/1755/ekonomi-indonesia-2019tumbuh-5-02-persen.html

Cnossen, S. (2015). What Kind of Corporation Tax Regime? Osgoode Hall Law Journal, 52(2), 513-551.

Darussalam. (2020). Perlukah Indonesia Menurunkan Tarif PPh Badan? DDTC News. https://news.ddtc.co.id/perlukah-indonesia-menurunkan-tarif-pph-badan19693?page_y=1333.3333740234375

Darussalam, Septriadi, D., \& Kristiaji, B. B. (2020). Policy Note: Omnibus Law Ketentuan \& Fasilitas Perpajakan untuk Penguatan Perekonomian.

Devereux, M. P., \& Maffini, G. (2006). The Impact of Taxation on the Location of Capital, Firms and Profit: A Survey of Empirical Evidence. European Tax Policy Forum, April, 1-52.

Diamastuti, E., \& Hardanti, K. N. (2019). The Investigation of Taxpayer Compliance in Tax Amnesty. Jurnal Akuntansi, 10(2), 85-104.

Dietsch, P. (2015). Catching Capital: The Ethics of Tax Competition. Oxford Univesity Press.

Direktorat Jenderal Pajak RI. (2020). Undang-Undang Nomor 11 Tahun 2020, Klaster Kemudahan Berusaha: Bidang Perpajakan. https://uu-ciptakerja.go.id/wpcontent/uploads/2020/11/Klaster-Kemudahan-Berusaha-Bidang-Perpajakan.pdf

Firmansah, B., \& Rahayu, N. (2020). Analysis of Indonesian Tax Authority Readiness in Taxation of Digital Economy in accordance with the OECD BEPS Action Plan 1 Recommendations. International Journal of Scientific and Research Publications, 10(7), 265-273.

Fleming, J. C., Peroni, R. J., \& Shay, S. E. (2008). Some Perspectives from the United States on the Worldwide Taxation vs. Territorial Taxation Debate. Journal of the Australasian Tax Teachers Association, 3(2), 83-106.

Harris, P. (2013). Corporate Tax Law: Structure, Policy, and Practice. Cambridge University Press.

Huibregtse, S., \& Sood, A. (2016). Digital Economy Handbook 2016: Tax, Transfer Pricing and Other Legal Aspects of Business Configurations. CreateSpace Independent Publishing Platform.

Kee-hong, B., \& Jisok, K. (2017). Does the Economy Ruin the Stock Market or Does the Stock Market Ruin the Economy? Journal of Financial Economics, March, 1.

Keen, M., \& Simone, A. (2004). Tax Policy in Developing Countries: Some Lessons from the 1990s and some Challenges Ahead. In Helping Countries Develop: The Role of Fiscal Policy (Vol. 10, Issue 4, pp. 720-722).

Kementerian Keuangan RI. (2019). Naskah Akademik Rancangan Undang-Undang Tentang Ketentuan dan Fasilitas Perpajakan Untuk Penguatan Perekonomian.

Kitchenham, B., \& Charters, S. (2007). Guidelines for performing Systematic Literature Reviews in Software Engineering. In EBSE Technical Report.

KPMG. (2020). Corporate Tax Rates for 2010-2020. https://home.kpmg/xx/en/home/services/tax/tax-tools-and-resources/tax-ratesonline/corporate-tax-rates-table.html

Kumar, A. (2020). Did Tax Cuts and Jobs Act Create Jobs and Stimulate Growth? Early 
Evidence Using State-Level Variation in Tax Changes. Federal Reserve Bank of Dallas, Working Papers, 2020(2001).

Mankiw, N. G. (2018). Principles of Economics. Cengage Technology.

Mooij, R. De, \& Saito, I. (2014). Japan's Corporate Income Tax: Facts, Issues, and Reform Options. In IMF Working Paper.

Nassaji, H. (2015). Qualitative and descriptive research: Data type versus data analysis. Language Teaching Research, 19(2), 129-132.

OECD. (2010). Choosing a Broad Base - Low Rate Approach to Taxation.

OECD. (2015). Addressing the Tax Challenges of the Digital Economy, Action 1 - 2015 Final Report.

OECD. (2017). IMF/OECD Reports for the G20 Finance Ministers.

OECD. (2018). Tax Policy Reforms 2018: OECD and Selected Partner Economies.

OECD. (2019). Tax Policy Reforms 2019: OECD and Selected Partner Economies.

OECD. (2020). Corporate Tax Statistics Database.

Owens, J. (2019). Cooperative Compliance. July. http://pravoisuspilstvo.org.ua/archive/2018/4_2018/part_1/39.pdf

Petticrew, M., \& Roberts, H. (2006). Systematic Reviews in the Social Sciences: A Practical Guide. In Systematic Reviews in the Social Sciences: A Practical Guide. Blackwell Publishing.

Riyanto, S., Sumardjono, M. S. W., Sulistiowati, \& Hiariej, E. O. S. (2020). Kertas Kebijakan: Catatan Kritis Terhadap UU No 11 Tahun 2020 Tentang Cipta Kerja.

Stewart, M. (2015). Abuse and Economic Substance in a Digital BEPS World. Bulletin for International Taxation (IBFD), June/July.

Stiglitz, J. E. (2000). Economics of the Public Sector. In Economics of the public sector. W.W. Norton \& Company.

Suratman, E. (2009). Pengaruh Pajak Penghasilan Terhadap Kesejahteraan: Suatu Model Teoritis. Jurnal Ekonomi Pembangunan: Kajian Masalah Ekonomi Dan Pembangunan, 10(1), 125.

Tax Policy Center. (2017). Analysis of the Tax Cuts and Jobs Act. Tax Policy Center Urban Institute and Brookings Institution. https://www.taxpolicycenter.org/feature/analysistax-cuts-and-jobs-act

Tempo. (2019). BKF Kaji Dampak Penurunan Tarif PPh Badan ke Penerimaan Negara. https://bisnis.tempo.co/read/1222826/bkf-kaji-dampak-penurunan-tarif-pph-badan-kepenerimaan-negara

Victor, L. (2008). Systematic Reviewing. Social Research Update, 54, 1-4.

Wagner, C., Kawulich, B., \& Garner, M. (2012). Doing Social Research: A Global Context. In Routledge Handbook of Research Methods in Military Studies. McGrawHill Higher Education.

World Bank. (2020). Doing Business 2020: Indonesia. In Doing Business 2020, Economy Profile Indonesia. https://www.doingbusiness.org/en/reports/global-reports/doingbusiness-2020 